\title{
Toward a Feminist Poetics of Narrative Voice
}

Why this privileged relationship with the voice?

-Hélène Cixous, "The Laugh of the Medusa"

F ew words are as resonant to contemporary feminists as "voice." The term appears in history and philosophy, in sociology, literature, and psychology, spanning disciplinary and theoretical differences. Book titles announce "another voice," a "different voice," or resurrect the "lost voices" of women poets and pioneers; fictional figures ancient and modern, actual women famous and obscure, are honored for speaking up and speaking out. ${ }^{1}$ Other silenced communities-peoples of color, peoples struggling against colonial rule, gay men and lesbians-have also written and spoken about the urgency of "coming to voice." Despite compelling interrogations of "voice" as a humanist fiction, for the collectively and personally silenced the term has become a trope of identity and power: as Luce Irigaray suggests, to find a voice (voix) is to find a way (voie). ${ }^{2}$

1. A few titles: In a Different Voice; American Women, American Voices; The Sound of Our Own Voices; The Other Voice: Scottish Women's Writing since 1808; Finding a Voice: Asian Women in Britain; Territories of the Voice: Contemporary Stories by Irish Women Writers; Radical Voices: A Decade of Resistance from "Women's Studies International Forum"; The Indigenous Voice: Visions and Realities.

2. Luce Irigaray, This Sex Which is Not One, trans. Catherine Porter with Carolyn Burke (Ithaca: Cornell University Press, 1985), 209. As my references to Cixous and Irigaray emphasize, even "poststructuralist" feminists have been unwilling to abandon the word voice as a signifier of female power, for women have not as a body (in both senses) possessed the logos that deconstruction deconstructs. 
In narrative poetics ("narratology"), voice is an equally crucial though more circumscribed term, designating tellers-as distinct from both authors and nonnarrating characters-of narrative. Although many critics acknowledge the bald inaccuracy of "voice" and "teller" to signify something written, these terms persist even among structuralists: according to Gérard Genette, "in the most unobtrusive narrative, someone is speaking to me, is telling me a story, is inviting me to listen to it as he tells it." 3 Narration entails social relationships and thus involves far more than the technical imperatives for getting a story told. The narrative voice and the narrated world are mutually constitutive; if there is no tale without a teller, there is no teller without a tale. This interdependence gives the narrator a liminal position that is at once contingent and privileged: the narrator has no existence "outside" the text yet brings the text into existence; narrative speech acts cannot be said to be mere "imitations," like the acts of characters, because they are the acts that make the "imitations" possible.

Despite their shared recognition of the power of "voice," the two concepts I have been describing-the feminist and the narratological-have entailed separate inquiries of antithetical tendency: the one general, mimetic, and political, the other specific, semiotic, and technical. When feminists talk about voice, we are usually referring to the behavior of actual or fictional persons and groups who assert womancentered points of view. Thus feminists may speak of a literary character who refuses patriarchal pressures as "finding a voice" whether or not that voice is represented textually. When narrative theorists talk about voice, we are usually concerned with formal structures and not with the causes, ideologies, or social implications of particular narrative practices. With a few exceptions, feminist criticism does not ordinarily consider the technical aspects of narration, and narrative poetics does not ordinarily consider the social properties and political implications of narrative voice. ${ }^{4}$ Formalist poetics may seem to fem-

3. Gérard Genette, Narrative Discourse Revisited, trans. Jane E. Lewin (Ithaca: Cornell University Press, 1988), 101. I consider this distinction not essential but conventional: narratives have narrators because Western literature has continued to construct reading and listening in speakerly terms. The convention may already be disappearing in an age of mechanical reproduction, bureaucratic discourse, and computer-generated texts. For an opposing viewpoint, see Jonathan Culler, "Problems in the Theory of Fiction," Diacritics 14 (Spring 1984): 5-11.

4. On the tension between feminism and narrative poetics see Robyn Warhol, Gendered Interventions: Narrative Discourse in the Victorian Novel (New Brunswick, N.J.: Rutgers University Press, 1989), 12-20; my essay "Toward a Feminist Narratology," Style 20 (1986): 341-63; and my subsequent exchange with Nilli Diengott in Style 22 (1988): 40-6o. 
inists naively empiricist, masking ideology as objective truth, sacrificing significance for precision, incapable of producing distinctions that are politically meaningful. Feminist criticism may seem to narratologists naively subjectivist, sacrificing precision for ideology, incapable of producing distinctions that are textually meaningful.

These incompatible tendencies, which I have overstated here, can offer fruitful counterpoints. As a narratological term, "voice" attends to the specific forms of textual practice and avoids the essentializing tendencies of its more casual feminist usages. As a political term, "voice" rescues textual study from a formalist isolation that of ten treats literary events as if they were inconsequential to human history. When these two approaches to "voice" converge in what Mikhail Bakhtin has called a "sociological poetics," it becomes possible to see narrative technique not simply as a product of ideology but as ideology itself: narrative voice, situated at the juncture of "social position and literary practice,"6 embodies the social, economic, and literary conditions under which it has been produced. ${ }^{7}$ Such a sociological or materialist poetics refuses the idealism to which both narrative poetics and some forms of feminist theory have been prone, an idealism that has led in the first case to a reading of textual properties as universal, inevitable, or random phenomena, and in the second to the assumption of a panhistorical "women's language" or "female form." I maintain that both narrative structures and women's writing are determined not by essential properties or isolated aesthetic imperatives but by complex and changing conventions that are themselves produced in and by the relations of power that implicate writer, reader, and text. In modern Western societies during the centuries of "print culture" with which I am concerned, these constituents of power must include, at the very least, race, gender, class, nationality, education, sexuality

5. A "sociological poetics" is described in P. N. Medvedev and M. M. Bakhtin, The Formal Method in Literary Scholarship: A Critical Introduction to Sociological Poetics, trans. Albert J. Wehrle (Baltimore: Johns Hopkins University Press, 1978), 30. The feminist attention to voice generated by Bakhtinian theory is a welcome new inquiry; see especially Dale M. Bauer, Feminist Dialogics: A Theory of Failed Community (Albany: SUNY Press, 1988). On the whole, however, "feminist dialogics" have not focused on the close formal distinctions found, for example, in Bakhtin's "Discourse on the Novel," but have followed Bakhtin's tendency elsewhere to equate "voice" with discourse in the Foucauldian sense.

6. Raymond Williams, Marxism and Literature (Oxford: Oxford University Press, 1977), 179 .

7. I am using "ideology" throughout to describe the discourses and signifying systems through which a culture constitutes its beliefs about itself, structures the relationships of individuals and groups to one another, to social institutions, and to belief systems, and legitimates and perpetuates its values and practices. This definition does not address the question of whether there is a "real" outside ideology that is not itself ideological. 
and marital status, interacting with and within a given social formation.

So long as it acknowledges its own status as theory rather than claiming to trade in neutral, uninterpreted facts, a historically-situated structuralist poetics may offer a valuable differential framework for examining specific narrative patterns and practices. The exploration of narrative structures in women's writings may, in turn, challenge the categories and postulates of narratology, since the canon on which narrative theory is grounded has been relentlessly if not intentionally man-made. ${ }^{8}$ As one contribution to such a feminist poetics of narrative, this book explores certain configurations of textual voice in fictions by women of Britain, France, and the United States writing from the mid-eighteenth century to the mid-twentieth-the period that coincides with the hegemony of the novel and its attendant notions of individual(ist) authorship. Recognizing that the "authorfunction" that grounds Western literary authority is constructed in white, privileged-class male terms, ${ }^{9}$ I take as a point of departure the hypothesis that female voice-a term used here simply to designate the narrator's grammatical gender-is a site of ideological tension made visible in textual practices.

In thus linking social identity and narrative form, I am postulating that the authority of a given voice or text is produced from a conjunction of social and rhetorical properties. Discursive authority-by which I mean here the intellectual credibility, ideological validity, and aesthetic value claimed by or conferred upon a work, author, narrator, character, or textual practice-is produced interactively; it must therefore be characterized with respect to specific receiving communities. In Western literary systems for the past two centuries, however, discursive authority has, with varying degrees of intensity, attached itself most readily to white, educated men of hegemonic ideology. One major constituent of narrative authority, therefore, is the extent to which a narrator's status conforms to this dominant social power. At the same time, narrative authority is also constituted through (historically changing) textual strategies that even socially unauthorized

8. Nor is this true only of formalist critics like Genette, Shlomith Rimmon-Kenan, Wolfgang Iser, and (less egregiously) Seymour Chatman. The work of materialists like Fredric Jameson and even Bakhtin, which has been so enthusiastically embraced by critics working with "marginal" discourses, is androcentric in both its textual canon and its assumptions about literature. 9. On the "author-function" see Michel Foucault, "What Is an Author?" in Language, Counter-Memory, Practice: Selected Essays and Interviews, ed. Donald F. Bouchard (Ithaca: Cornell University Press, 1977), $113-38$. 
writers can appropriate. Since such appropriations may of course backfire, nonhegemonic writers and narrators may need to strike a delicate balance in accommodating and subverting dominant rhetorical practices.

Although I have been speaking about authority as if it were universally desirable, some women writers have of course questioned not only those who hold authority and the mechanisms by which they are authorized, but the value of authority as modern Western cultures have constructed it. I believe, however, that even novelists who challenge this authority are constrained to adopt the authorizing conventions of narrative voice in order, paradoxically, to mount an authoritative critique of the authority that the text therefore also perpetuates. Carrying out such an Archimedean project, which seems to me particularly hazardous for texts seeking canonical status, necessitates standing on the very ground one is attempting to deconstruct. While I will acknowledge ways in which women writers continue to challenge even their own authoritative standing, the emphasis of this book is on the project of self-authorization, which, I argue, is implicit in the very act of authorship. In other words, I assume that regardless of any woman writer's ambivalence toward authoritative institutions and ideologies, the act of writing a novel and seeking to publish it-like my own act of writing a scholarly book and seeking to publish it-is implicitly a quest for discursive authority: a quest to be heard, respected, and believed, a hope of influence. I assume, that is, that every writer who publishes a novel wants it to be authoritative for her readers, even if authoritatively antiauthoritarian, within the sphere and for the receiving community that the work carves out. In making this assumption I am not denying what Edward Said calls the "molested" or "sham" nature of textual authority in general and of fictional authority in particular, but I am also reading the novel as a cultural enterprise that has historically claimed and received a truth value beyond the fictional. ${ }^{10}$

I have chosen to examine texts that engage questions of authority specifically through their production of narrative voice. In each case, narrative voice is a site of crisis, contradiction, or challenge that is manifested in and sometimes resolved through ideologically charged

10. See Edward Said, "Molestation and Authority in Narrative Fiction," in Aspects of Narrative: Selected Papers from the English Institute, ed. J. Hillis Miller (New York: Columbia University Press, 1971), 47-68. On the status of fiction see also Peter J. McCormick, Fictions, Philosophies, and the Problems of Poetics (Ithaca: Cornell University Press, 1988). 
technical practices. The texts I explore construct narrative voices that seek to write themselves into Literature without leaving Literature the same. These narrators, skeptical of the authoritative aura of the male pen and of ten critical of male dominance in general, are nonetheless pressed by social and textual convention to reproduce the very structures they would reformulate. Such narrators of ten call into question the very authority they endorse or, conversely, endorse the authority they seem to be questioning. That is, as they strive to create fictions of authority, these narrators expose fictions of authority as the Western novel has constructed it-and in exposing the fictions, they may end up re-establishing the authority. Some of these texts work out such dilemmas on their thematic surfaces, constructing fictions of - that is, about-authority, as well.

When I describe these complexities in some women's writings I am not, however, suggesting any kind of "authentic" female voice or arguing that women necessarily write differently from men. Rather, I believe that disavowed writers of both sexes have engaged in various strategies of adaptation and critique that make their work "dialogical" in ways that Bakhtin's formulation, which posits heteroglossia as a general modern condition, may obscure. ${ }^{11}$ It is possible, for example, that women privileged enough to write literature are particularly susceptible to what Margaret Homans describes as "a specific genderbased alienation from language" born of the "simultaneous participation in and exclusion from a hegemonic group." 12 My reading suggests that different communities of women have had different degrees of access to particular narrative forms. I am especially interested in those female narrators who claim public authority, since within the historical period I am studying it has not been voice in general so much as public voice that women have been denied. As I will suggest further on in this chapter, these concerns lead me less to a new narrative poetics than to a poetics attentive to issues that conventional narratology has devalued or ignored.

11. Bakhtin's formulation that all novelistic discourse, if not all discourse, is irreducibly double-voiced makes more difficult the differentiating of specific ways in which the words of a disauthorized community are "entangled, shot through with shared thoughts, points of view, alien value judgments and accents," and dwell in "a dialogically agitated and tensionfilled environment of alien words" (The Dialogic Imagination, trans. Caryl Emerson and Michael Holquist [Austin: University of Texas Press, 1981], 276).

12. Margaret Homans, "'Her Very Own Howl': The Ambiguities of Representation in Recent Women's Fiction," Signs (1983): 205. Homans's suggestion that this ambiguity characterizes all women's discourse seems to me problematic insofar as it presumes that all women are simultaneously inside and outside a hegemony. 
Before describing more fully the focus of this book, I want to illustrate the complex dynamics that may govern a specific production of female voice by turning to a curious document that appeared in Atkinson's Casket in April $1832::^{13}$

\section{FEMALE INGENUITY.}

Secret Correspondence.-A young Lady, newly married, being obliged to show her husband, all the letters she wrote, sent the following to an intimate friend.

I cannot be satisfied, my Dearest Friend!

blest as I am in the matrimonial state, unless I pour into your friendly bosom, which has ever been in unison with mine, the various deep sensations which swell with the liveliest emotions of pleasure my almost bursting heart. I tell you my dear husband is one of the most amiable of men, I have been married seven weeks, and have never found the least reason to repent the day that joined us, my husband is in person and manners far from resembling ugly, crass, old, disagreeable, and jealous monsters, who think by confining to secure; a wife, it is his maxim to treat as a bosom-friend and confidant, and not as a play thing or menial slave, the woman chosen to be his companion. Neither party he says ought to obey implicitly;but each yield to the other by turnsAn ancient maiden aunt, near seventy, a cheerful, venerable, and pleasant old lady, lives in the house with us-she is the delight of both young and old-she is civil to all the neighbourhood round, generous and charitable to the poorI know my husband loves nothing more than he does me; he flatters me more than the glass, and his intoxication (for so I must call the excess of his love,)

13. I discovered this letter accidentally some years ago in The Genteel Female, ed. Clifton Furness (New York: Knopf, 1931). On that book's endpaper is reproduced the page from Atkinson's Casket that includes this letter, sandwiched between a commentary on angels and directions for calisthenic exercise. For a discussion of other aspects of the letter, including its "plot," see my essay "Toward a Feminist Narratology," 346-57. 
of ten makes me blush for the unworthiness

of its object, and I wish I could be more deserving

of the man whose name I bear. To

say all in one word, my dear, _

crown the whole, my former gallant lover

is now my indulgent husband, my fondness

is returned, and I might have had

a Prince, without the felicity I find with

him. Adieu! May you be as blest as I am un-

able to wish that I could be more

happy.

For those who believe in a "women's language" that is "polite, emotional, enthusiastic, gossipy, talkative, uncertain, dull, and chatty," 14 or "weak, trivial, ineffectual, tentative, hesitant, hyperpolite, euphemistic, and ... marked by gossip and gibberish," 15 this text might be hailed as perfect evidence. Its self-effacing writer, who blushes at her own "unworthiness," nonetheless cannot "say all in one word"; repetition, hyperbole, convolution, and grammatical anomaly are the pervasive structures of her text. It has been argued that such selfdeprecating, uncertain, and verbose discourse, which women in certain circumstances have supposedly been encouraged to adopt, also undermines its own authority. ${ }^{16}$

But let us recall that this bride was obliged to show the letter to her husband; a note at the bottom of the Casket entry tells us that "the key to the above letter, is to read the first and then every alternate line":

I cannot be satisfied, my dearest Friend! unless I pour into your friendly bosom, the various deep sensations which swell my almost bursting heart. I tell you my dear I have been married seven weeks, and repent the day that joined us, my husband is ugly, crass, old, disagreeable, and jealous[;] a wife, it is his maxim to treat as a play thing or menial slave, the woman he says ought to obey implicitly;-

14. Cheris Kramarae, "Proprietors of Language," in Women and Language in Literature and Society, ed. Sally McConnell-Ginet, Ruth Borker, and Nelly Furman (New York: Praeger, 1980), 58.

15. Dale Spender, Man Made Language (London: Routledge, 1980), 33.

16. Robin Lakoff, Language and Woman's Place (New York: Harper and Row, 1975), 7. 
An ancient maiden aunt, near seventy, lives in the house with us-she is the devil to all the neighbourhood round, I know my husband loves nothing more than the glass, and his intoxication often makes me blush for the unworthiness of the man whose name I bear. To crown the whole, my former gallant lover is returned, and I might have had him. Adieu! may you be as blest as I am unhappy.

If the surface letter is virtually a sampler of what has passed for "women's language," this "subtext" is an equally striking example of what might stereotypically be called "men's language": it is "capable, direct, rational," "strong," 17 "forceful, efficient, blunt, authoritative, serious, effective, sparing and masterful." 18 This narrator, writing for a sister's eye, shows herself angry, decisive, judgmental, acutely aware of her husband's deficiencies and her own lost opportunities. Beneath the putatively feminine voice of effusive self-effacement lies the putatively masculine voice of indignant self-assertion, which the writer cannot inscribe in the more public version of her text. These formal differences between the letters, which share the same originating female voice, are clearly not differences in the sex of the narrator, though they may be attributable to differences in the sex of the narratee. The "feminine style" of the surface text, that "powerless," nonauthoritative form called "women's language," here becomes a powerfully subversive mask for telling secrets to a woman under the watchful eyes of a man. In Irigaray's terms, the surface letter is a "disruptive excess," a "mimicry": it deliberately adopts a "feminine" position that is exaggerated into subversion by exposing the mechanisms of its own abjection (thereby revealing at the same time its dependence upon "the words of the powerful"). ${ }^{19}$ The female voice conforms in order to "con" form: "women's language" becomes a calculated response to alienation and censorship, an evasion of material threat.

I will argue, however, that this discourse is not simply "women's language" -or even, as some linguists would have it, a universal "lan-

17. Kramarae, "Proprietors of Language," 58.

18. Spender, Man Made Language, 33.

19. Irigaray, This Sex Which Is Not One, 76-78; Sheila Rowbotham, Woman's Consciousness, Man's World (Harmondsworth, England: Penguin, 1973), 32. 
guage of the powerless"-but the product of a particular set of stereotypes that become codified in Victorian gender ideologies. This language is associated specifically with the "lady" who maintains her position through a conscious or unconscious discourse of devotion to the men who control her life. It is less the language of women than the language of wives: the woman in this text-the independent human of female sex-is in fact represented by the voice whose language would be called "masculine." In other words, in this blatantly dialogized discourse, both voices are female; "female voice" is not an "essence" but a variable subject position whose "I" is grammatically feminine. The particular characteristics of any "female voice," then, are a function of the context in which that voice operates.

This context, moreover, is less simple than it appears. Because the letter is deliberately coded, the subtext makes the surface letter seem only a fiction and the hidden message all the "truth." In this case "women's language" becomes a code adopted to confuse a male "public," as if privately - that is, to another woman-a woman can simply say what she means. But this opposition deconstructs itself when one asks how two such disparate narratives can produce a continuous text. The articulation between surface and subtext, the syntactic hinge that binds and finally transforms the whole, is a set of negative constructions that the decoding process pares away:

\footnotetext{
I [ . . have never found the least reason to] repent my husband is ... [far from resembling] ugly, crass, old... a wife, it is his maxim to treat... [not] as a plaything [Neither party], he says, ought to obey implicitly I am un[able to wish that I could be more] happy-
}

This negativity turns out to be more than the link between texts; it makes the surface text not simply a proclamation of one woman's marital happiness but an indirect indictment of marriage itself. In its negations, the surface letter written "for" the husband describes as normative the kind of marriage the writer claims to have escaped; each statement about the speaker's good fortune implies a norm in which brides repent their marriages, husbands are monstrous, and women are "playthings" or "slaves." Thus, by saying what one marriage is not, the surface text shows what its narrator expected marriage to be. While the subtext condemns one husband and laments one bride's fate-suggesting that the writer has merely married the 
"wrong" man-the surface letter condemns marriage itself, presenting as typical the conditions that seem in the subtext to be individual. The subtext, with its portrait of a miserable bride, thus becomes an illustration of the surface text rather than its antithesis, and it is fitting that the two versions meet only in a shared dissatisfaction, in the single line that does not change: "I cannot be satisfied, my dearest Friend!"

Even without the subtext, then, the surface letter is already doublevoiced, representing in one discourse both the uncritical acceptance of one marriage and a critical rejection of marriage itself. This doubleness also means that the surface letter is at least as authoritative as the hidden undertext, that authority resides not simply in "men's language" (which in this case is asserting only an individual, experiential "truth"), but also in the indirection of a censored and stereotypically "feminine" form. Nor is this letter simply a "palimpsest" in which "surface designs conceal or obscure deeper, less accessible (and less socially acceptable) levels of meaning,"20 for this "surface design" turns out to carry meanings at least as disturbing as the subtext it purports to protect.

I have explored this letter in some detail not to reinforce notions of discursive sexual difference but, on the contrary, to suggest the complexity and specificity of (women's) narrative practices even in obviously coded texts. Underscoring crucial differences of function and form between "private" and "public" discourse, the letter represents its own formal practices as neither arbitrary nor simply representational, but as responses to situational imperatives produced by the relations of power that acts of telling entail. Narrative status, contact, and stance are revealed to be mutually constitutive: the ways in which narrators represent themselves, the relationships they construct with narratees, and the ideological and affective positions they take are dynamic and interdependent elements. In illustrating the intricacies of narrative strategy in a culture that censors female voice, and the specificity of different narrative constructions for different audiences and purposes, the letter asks those who would not be deceived "husbands" not only to read beneath surfaces but to read surfaces anew, not only to read manifest "content" but to read the content of manifest "form." And if the letter as private correspondence seems to figure the male as the duped reader and the female as the ideal 
one, the letter as a public document has as its audience the unidentified reader of either sex who, presented with the text as it appeared in Atkinson's Casket, can read beyond the immediate context of the letterwriter's circumstances to understand "female ingenuity" as cultural critique.

Finally, the publication of this letter in 1832 , in a city where AfricanAmerican and white women were becoming involved in abolitionist activity (the Philadelphia Female Anti-Slavery Society was founded in 1833), suggests that the relationship between patriarchy and slavery implicit in the reference to the wife as a "menial slave" may be more than casual: it both raises the problematic history of white women's appropriation of slavery by analogy $y^{21}$ and reminds us that American slaves also made extensive use of coding in order to evade censorship. It seems doubly appropriate, then, that "ingenuity" means not only a paradoxical blend of skillful design and apparent openness but also, according to the $O E D$, "the quality or condition of being a free-born man." In theory, writing becomes a powerful site of transformation to this "condition" of freedom insofar as writing may be detached from its producing subject. The public circulation of texts by women has thus posed a pervasive threat to patriarchy, as the public circulation of slave writings posed a pervasive threat to slavery, and these threats may explain why the forms and performances of women and peoples of color have of ten been devalued as mere "ingenuity."

Atkinson's Casket presents the bride's letter without revealing the circumstances of its composition, the identity of its composer, or the process by which it came to be a public text. If, as I suspect, the letter is apocryphal (that is, not an actual bride's correspondence), it is double-voiced in yet another sense: it has represented fiction as history. The voice that introduces the letter becomes its authorizing agent and the letter-writer a fictional narrator created to perform a politically motivated exercise in "ingenuity." Fiction becomes a set of strategies for mitigating the audacity of opposition, and the very fact of the fiction becomes evidence of a censorship subtler but no less significant than that imposed on the young bride. Private voice (here,

21. I mean here the use of analogies with slavery not as a way of combating slavery but as a way of legitimating women's rights. Although I do not doubt the conscious intentions of those Americans and Europeans who made such analogies in the eighteenth and nineteenth centuries, I believe they tended to work more to the benefit of white women than to that of slaves. The same holds for contemporary analogies between "women" and "blacks," which also risk erasing black women because "women" comes to imply white women, and "blacks," black men. 
the voice of the bride addressing only her closest female friend) becomes an enabling strategy for writing what is manifestly forbidden as "public" narrative. To other compelling explanations for women's historical association with the novel-its formal and thematic pliability at the time when women began writing in significant numbers; its ambiguous status as literature; its feasibility as a source of both income and discursive power-one must surely add the opportunities the novel affords for creating voices on the margins of fiction and history that both mask and enable the most challenging fictions of authority.

This book begins with the simultaneous "rise" of the novel and emergence of modern gender identity in the mid-eighteenth century, and moves toward what may well be the twilight of both. As I situate narrative practices in relation to literary production and social ideology, I will be asking what forms of voice have been available to women, and to which women, at particular moments. My intention is to explore through specifically formal evidence the intersection of social identity and textual form, reading certain aspects of narrative voice as a critical locus of ideology.

I have organized the book to focus on changing problems and patterns in the articulation of three narrative modes which I call, respectively, authorial, personal, and communal voice. Each mode represents not simply a set of technical distinctions but a particular kind of narrative consciousness and hence a particular nexus of powers, dangers, prohibitions, and possibilities. Across all three modes, however, I will be concerned with two aspects of narration that I consider of greater significance in the construction of textual authority than narrative poetics has traditionally allowed. The first is the distinction between private voice (narration directed toward a narratee who is a fictional character) and public voice (narration directed toward a narratee "outside" the fiction who is analogous to the historical reader). The second is the distinction between narrative situations that do and those that do not permit narrative self-reference, by which I mean explicit attention to the act of narration itself. It is my hypothesis that gendered conventions of public voice and of narrative self-reference serve important roles in regulating women's access to discursive authority.

I use the term authorial voice to identify narrative situations that are heterodiegetic, public, and potentially self-referential. (Gérard Genette, observing that every narrator is potentially an enunciating "I," 
suggests the more precise term heterodiegetic for what is traditionally called "third-person" narration in which the narrator is not a participant in the fictional world and exists on a separate ontological plane from the characters. ${ }^{22}$ ) The mode I am calling authorial is also "extradiegetic" and public, directed to a narratee who is analogous to a reading audience. ${ }^{23} \mathrm{I}$ have chosen the term "authorial" not to imply an ontological equivalence between narrator and author but to suggest that such a voice (re)produces the structural and functional situation of authorship. In other words, where a distinction between the (implied) author and a public, heterodiegetic narrator is not textually marked, readers are invited to equate the narrator with the author and the narratee with themselves (or their historical equivalents). This conventional equation gives authorial voice a privileged status among narrative forms; as Bakhtin states, while the discourse of a character or a stylized narrator is always a contingent "object of authorial understanding," authorial discourse is "directed toward its own straightforward referential meaning." ${ }^{24}$ Moreover, since authorial narrators exist outside narrative time (indeed, "outside" fiction) and are not "humanized" by events, they conventionally carry an authority superior to that conferred on characters, even on narrating characters. In using the term "authorial" I mean as well to evoke Franz Stanzel's distinction in Narrative Situations in the Novel between "authorial" and "figural" modes: while authorial narrative permits what I am calling narrative self-reference, in the "figural" mode all narration is focalized through the perspectives of characters, and thus no reference to the narrator or the narrative situation is feasible.

I want to suggest as a major element of authorial status a distinction between narrators who engage exclusively in acts of representationthat is, who simply predicate the words and actions of fictional characters-and those who undertake "extrarepresentational" acts: reflections, judgments, generalizations about the world "beyond" the fiction, direct addresses to the narratee, comments on the narrative process,

22. Gérard Genette, Narrative Discourse: An Essay in Method, trans. Jane E. Lewin (Ithaca: Cornell University Press, 1980), 244-45.

23. On the concept of diegetic levels, see ibid., 227-31. On the distinction between private and public voice, which is not identical to Genette's distinction between primary and inserted narrative, see my book The Narrative Act: Point of View in Prose Fiction (Princeton: Princeton University Press, 1981), 133-48, and "Toward a Feminist Narratology," 350-55.

24. Mikhail Bakhtin, Problems of Dostoevsky's Poetics, ed. and trans. Caryl Emerson (Minneapolis: University of Minnesota Press, 1984), 187. 
allusions to other writers and texts. ${ }^{25} \mathrm{I}$ will be using the term overt authoriality or simply authoriality, to refer to practices by which heterodiegetic, public, self-referential narrators perform these "extrarepresentational" functions not strictly required for telling a tale. I am speculating that acts of representation make a more limited claim to discursive authority than extrarepresentational acts, which expand the sphere of fictional authority to "nonfictional" referents and allow the writer to engage, from "within" the fiction, in a culture's literary, social, and intellectual debates. On the other hand, as Shlomith Rimmon-Kenan has observed, when a narrator "becomes more overt, his chances of being fully reliable are diminished, since his interpretations, judgements, generalizations are not always compatible with the norms of the implied author."26

Extrarepresentational acts are especially critical to a polyglossic genre like the novel because they enable the narrator to construct the "maxims" that Genette describes as the foundation of verisimilitude. ${ }^{27}$ In other words, the reception of a novel rests on an implicit set of principles by which textual events (for example, characters' behaviors) are rendered plausible. To the degree that a text's values deviate from cultural givens (as they will to some degree in all but the most formulaic of fictions), they must be established (or inferred) for each narrative instance so that readers can construct the story as "plausible" and embed it in a "world view." ${ }^{28}$ Ideologically oppositional writers might wish, therefore, to "maxim-ize" their narratives in order either to posit alternative textual ideologies or to establish the writer, through her authorial narrator-equivalent, as a significant participant in contemporary debates-all the more during those periods when the novel was one of the few accepted means for women to intervene in public life.

It should not be difficult to understand why, with differences in kind and intensity according to time, place, and circumstance, women writers' adoption of overt authoriality has usually meant transgressing

25. Each of these "extrarepresentational" acts may of course be embedded in sentences of representation; the two activities are sometimes simultaneous.

26. Shlomith Rimmon-Kenan, Narrative Fiction: Contemporary Poetics (London: Methuen, 1983), 103 .

27. Gérard Genette, Figures II (Paris: Seuil, 1968).

28. On the importance of "maxim" see Nancy Miller, "Emphasis Added: Plots and Plausibilities in Women's Fiction," PMLA 96 (1981): 36 6-48; reprinted in TheNew Feminist Criticism, ed. Elaine Showalter (New York: Pantheon, 1985), 339-6o. 
gendered rhetorical codes. In cultures such as the ones I am examining, where women's access to public discourse has been curtailed, it has been one thing for women simply to tell stories and another for their narrators to set themselves forth as authorities. Indeed, authorial voice has been so conventionally masculine that female authorship does not necessarily establish female voice: a startling number of critics have referred in the generic masculine to the narrators of such novels as La Princesse de Clèves and Pride and Prejudice. ${ }^{29}$ Thus, on the one hand, since a heterodiegetic narrator need not be identified by sex, the authorial mode has allowed women access to "male" authority by separating the narrating "I" from the female body; it is of course in the exploitation of this possibility that women writers have used male narrators and pseudonyms (acts that may have profited individual writers or texts, but that have surely also reinforced the androcentrism of narrative authority). On the other hand, when an authorial voice has represented itself as female, it has risked being (dis)qualified. It is possible that women's writing has carried fuller public authority when its voice has not been marked as female.

The narrators I discuss in Part I of this book have sought not simply to tell stories, but through overtly authorial practices to make themselves (and, I presume, their authors) significant literary presences. After examining an eighteenth-century text that proclaims the difficulty of achieving authoriality, Part I focuses on four canonical writers (Jane Austen, George Eliot, Virginia Woolf, and Toni Morrison) in order to explore the means by which each has constructed authorial voice within and against the narrative and social conventions of her time and place. In the work of all four writers I see a reaching for narrative hegemony, for what Wayne Booth has called "direct and authoritative rhetoric,"30 that is obscured both by the writers' own disclaimers and by a tendency in contemporary feminist criticism to valorize "refusals" of authority in ways that seem to me ahistorical.

I use the term personal voice to refer to narrators who are selfconsciously telling their own histories. I do not intend this term to

29. For example, in The Dual Voice: Free Indirect Speech and Its Functioning in the NineteenthCentury European Novel (Manchester: Manchester University Press, 1977), Roy Pascal insists that Jane Austen's narrator be called by the "generic" masculine; Laurence Gregorio makes a similar insistence "for the sake of clarity" about La Princesse de Clèves in Order in the Court: History and Society in "La Princesse de Clèves" (Stanford French and Italian Studies 47, 1986), 1. For the argument that the unmarked narrative voice is neither gendered nor necessarily human, see Culler, "Problems in the Theory of Fiction."

3o. Wayne Booth, The Rhetoric of Fiction (Chicago: University of Chicago Press, 1961), 6. 
designate all "homodiegetic" or "first-person" narratives-that is, all those in which the voice that speaks is a participant in the fictional world-but only those Genette calls "autodiegetic," in which the "I" who tells the story is also the story's protagonist (or an older version of the protagonist). ${ }^{31}$ In my exploration of personal voice I will exclude forms such as the interior monologue, which are not selfconsciously narrative and which, like figural narration, cannot construct a situation of narrative self-reference.

The authority of personal voice is contingent in ways that the authority of authorial voice is not: while the autodiegetic "I" remains a structurally "superior" voice mediating the voices of other characters, it does not carry the superhuman privileges that attach to authorial voice, and its status is dependent on a reader's response not only to the narrator's acts but to the character's actions, just as the authority of the representation is dependent in turn on the successful construction of a credible voice. These differences make personal voice in some ways less formidable for women than authorial voice, since an authorial narrator claims broad powers of knowledge and judgment, while a personal narrator claims only the validity of one person's right to interpret her experience.

At the same time, personal narration offers no gender-neutral mask or distancing "third person," no refuge in a generic voice that may pass as masculine. ${ }^{32} \mathrm{~A}$ female personal narrator risks the reader's resistance if the act of telling, the story she tells, or the self she constructs through telling it transgresses the limits of the acceptably feminine. If women are encouraged to write only of themselves because they are not supposed to claim knowledge of men or "the world," when women have written only of themselves they have been labeled immodest and narcissistic, and criticized for displaying either their virtues or their faults. Moreover, because male writers have created female voices, the arena of personal narration may also involve a struggle over which representations of female voice are to be authorized.

Although authorial narration, with its omniscient privilege, is usually understood to be fictional, fiction in the personal voice is usually

31. See Genette, Narrative Discourse, 227-47.

32. Obviously, a woman writer may choose an explicitly male "I"-narrator, as dozens of women writers from Hannah More to the Brontës to Willa Cather and Marguerite Yourcenar have done. When I speak of the teller here, I am speaking of the female narrator, not the female writer. 
formally indistinguishable from autobiography. Given the precarious position of women in patriarchal societies, woman novelists may have avoided personal voice when they feared their work would be taken for autobiography. The use of personal voice also risks reinforcing the convenient ideology of women's writing as "self-expression," the product of "intuition" rather than of art; ${ }^{33}$ perhaps this is why Maxine Hong Kingston stated recently that she did not believe she would be a "real" novelist until she had written a book in the authorial voice. ${ }^{34}$ In view of these constraints, my discussion of personal voice is especially concerned with variations in the accessibility of public and private forms of personal voice to particular communities of women at particular moments in history. Part II attempts to interpret patterns of personal voice respectively in European women's writings from the late eighteenth to the mid-nineteenth century and in AfricanAmerican women's writings from the nineteenth century to the contemporary period.

Conventional narrative poetics has often viewed authorial and personal voices as formal antitheses, the one constituting the "diegetic" voice of a fictional author, the other constituting the "mimetic" voice of a character. Indeed, the two modes carry different forms of rhetorical authority: paradoxically, authorial narrative is understood as fictive and yet its voice is accorded a superior reliability, while personal narrative may pass for autobiography but the authority of its voice is always qualified. But the opposition is far from definite: the eyewitness narrator used, for example, in Aphra Behn's Oronooko (1688) and George Eliot's Scenes of Clerical Life transgresses the polarities of "third-person" and "first-person" narration that are usually assumed to be formally unbridgeable.

The tendency to oppose these modes also conceals similarities between them. Both forms bear the potential for public, self-referential narration and thus for enacting a relationship between "writer" and audience and indeed an entire "story" that is the story of the narration itself. Moreover, the narratological tendency to oppose authorial and

33. See, for example, Jean Larnac's argument that women's literary power resides in their ability to "feel vividly and immediately to release from themselves feelings they have just experienced, without waiting for the fruitful germinations that come from slow meditation," in Histoire de la littérature féminine en France (Paris: Kra, 1929), 111.

34. Maxine Hong Kingston, in a reading given at Georgetown University, April 1989. Kingston was ref erring to Tripmaster Monkey-His Fake Book (New York: Knopf, 1989), whose authorial voice, she says, is absolutely-and to her, unmistakably-female even though it is never marked as such. 
personal voices conceals the degree to which both forms are invested in singularity-in the presupposition that narration is individual. This narrative individualism that European cultures take for granted explains why authorial and personal voices have been so commonly practiced and so thoroughly analyzed, while so little attention has been given to intermediate forms such as that of Christa Wolf's Nachdenken über Christa T. (1967), in which the narrator is reconstructing the life of another woman but is also in some sense a protagonist herself, not simply an eyewitness or biographer.

This individualization of narrative also explains why my third mode, communal voice, is likewise a category of underdeveloped possibilities that has not even been named in contemporary narratology. By communal voice I mean a spectrum of practices that articulate either a collective voice or a collective of voices that share narrative authority. Because the dominant culture has not employed communal voice to any perceptible degree, and because distinctions about voice have been based primarily on the features of this dominant literature, there has been no narratological terminology for communal voice or for its various technical possibilities.

By communal narration I do not mean simply the use of an authorial voice that resorts to an inclusive "we" (as George Eliot's narrators sometimes do), nor the multiple narration Faulkner adopts in a novel like As I Lay Dying, nor the presentation of divergent and antithetical perspectives on the same events that characterizes epistolary novels such as Lady Susan and Les Liaisons dangereuses. I refer, rather, to a practice in which narrative authority is invested in a definable community and textually inscribed either through multiple, mutually authorizing voices or through the voice of a single individual who is manif estly authorized by a community. In Part III, I will distinguish three such possibilities that result from various confluences of social ideology with changing conventions of narrative technique: a singular form in which one narrator speaks for a collective, a simultaneous form in which a plural "we" narrates, and a sequential form in which individual members of a group narrate in turn. Unlike authorial and personal voices, the communal mode seems to be primarily a phenomenon of marginal or suppressed communities; I have not observed it in fiction by white, ruling-class men perhaps because such an "I" is already in some sense speaking with the authority of a hegemonic "we." My survey of communal voice in Part III moves from an exploration of constraints on communal voice in the eighteenth 
century, through "singular" manifestations in the nineteenth, to a range of formal possibilities available to modern and postmodern narratives.

Because the structures of both narration and plot in the Western novel are individualist and androcentric, the articulation of a communal female voice is not simply a question of discourse but almost always one of story as well. Although it is possible to represent female community without communal voice, it is difficult to construct communal voice without constructing female community. Communal voice thus shifts the text away from individual protagonists and personal plots, calling into question the heterosocial contract that has defined woman's place in Western fiction. My examination of more and less realized communal forms in the singular, sequential, and simultaneous modes suggests the political possibilities of constituting a collectice female voice through narrative. At the same time, communal voice might be the most insidious fiction of authority, for in Western cultures it is nearly always the creation of a single author appropriating the power of a plurality.

The three modes of narrative voice on which this book concentrates seem to me to represent three distinct kinds of authority that women have needed to constitute in order to make their place in Western literary history: respectively, the authority, to establish alternative "worlds" and the "maxims" by which they will operate, to construct and publicly represent female subjectivity and redefine the "feminine," and to constitute as a discursive subject a female body politic. Each form creates its own fictions of authority, making certain meanings and not others articulable. Although I begin with authorial voice because it is the oldest and most basic mode and end with communal voice because it is the newest and least conventional, I refrain from any absolute evaluation of the three modes. I will speculate briefly in my final chapter about the value of each of these narrative "tools" for dismantling, to use Audre Lorde's now-famous metaphor, the "master's house." 35

A book with a title as general as this one owes its readers some explanation of what it is and is not meant to be. In no way does it embraces the range of techniques and questions that are subsumed in the concept of "narrative voice." By choosing certain general cat-

35. Audre Lorde, “The Master's Tools Will Never Dismantle the Master's House," in Sister/ Outsider (Freedom, Calif.: Crossing Press, 1984), $110-13$. 
egories and distinctions, I hope to demonstrate that even the broadest, most obvious elements of narration are ideologically charged and socially variable, sensitive to gender differences in ways that have not been recognized. Because I have written this book for a general scholarly readership rather than for specialists in narratology, I have tried to keep technical terms to a minimum. Although I have introduced a few new concepts here, my earlier book, The Narrative Act: Point of View in Prose Fiction, describes in more detail most of the aspects of narrative voice on which this work relies.

In several ways this is a preliminary and speculative project. Because I focus on moments of crisis or breakthrough at which certain narrative practices become (im)possible, many important writers and literary events do not figure here. Nor do I mean to imply a linear growth in women's narrative authority: the history of voice in women's writings reflects what Mary Poovey affirms are "uneven developments." ${ }^{36}$ At the same time, narrative authority-like many other possibilities for women-is currently wider and deeper both for individuals and for previously silenced groups of women than it was two centuries ago, despite historical lapses and contemporary absences that remind us not to see any gains as inevitable, universal, or permanent.

The broad scope of the book makes my work preliminary in still other ways. Although the narrative poetics I envision is fully embedded in material-historical analysis, carrying out such a project would require engaging the conditions of cultural production for each individual text to an impossible degree given the broad historical and geographic arena that this book encompasses. In attempting to illuminate large patterns of voice in Western fiction, I have had to rely more on general developments in literary history than on particular developments in social and material life.

Because literary form has a far more uncertain relation to social history than does representational content, even a fully materialist poetics would be hard-pressed to establish definitive correspondences between social ideology and narrative form. I have nonetheless considered it fruitful to venture speculations about causal relationships that others may be able to establish or refute. Having learned from my biochemist friend Ellen Henderson that "how?" is a scientific ques-

36. Mary Poovey, Uneven Developments: The Ideological Work of Gender in Mid-Victorian England (Chicago: University of Chicago Press, 1988). 
tion but "why?" is not, I have sought through this project to show how particular writers and texts may have come to use particular narrative strategies.

Finally, this project remains rooted in Western theory and history. I am concerned that my "inclusion" of African-American novels places these texts in a eurocentric framework and thereby imposes the risk of perpetuating the distortions for which I fault literary history. My study does not explore the emerging novelistic traditions by women of Asia, Africa, and Latin America, and I mention only briefly some of the rich new fiction by Asian-American, Latina, Chicana, Arab, and Native American women in the United States. There remains a great deal to learn by studying narrative voice as it has been developing in countries and communities where women are just beginning to write, or where the novel is a relatively new genre produced through complex interactions between native and colonial forms. For this reason, especially, feminist criticism will need many more studies of women's fictions, studies focusing on many different cultures and from many different vantage points, before anyone can speak with authority about women writers and narrative voice. 